The Geneva Papers on Risk and Insurance, 20 (No. 77, October 1995) 501 -503

\title{
Comments on the European Project of Monetary Unification
}

\author{
by Robert Raymond*
}

1. Banks and near-banks are the usual partners of European central banks and the EMI. However, central bankers must pay attention to insurance companies and pension funds as they manage large portfolios. Ageing populations will inevitably increase their role.

Portfolio managers now collect a sizeable part of private savings. They are very professional. Their increasing, and now predominant, role has changed market behaviour. They contribute to the shaping of exchange rates, their swings and their volatility, through arbitrage operations.

Insurance companies should welcome the project of monetary unification at a regional level as a way of avoiding capital losses, reducing the need for hedging and reducing transaction costs. Such concerns are also relevant for the corporate sector, especially among countries whose economies are closely integrated. There is no single market without a single currency, a single pricing mechanism being one of the features of a level playing-field for businesses.

When deviating from the purchasing power parity, exchange rate changes are trade barriers. The undervaluation of a national currency is a substitute for import duties and export subsidies. Such misalignments disturb competitiveness, in a way which is unpredictable. Not only is this incompatible with the creation of a large domestic market including several European countries, in order to increase growth and employment, but uncertainty as such freezes investment projects by casting doubts on the return on capital.

Proof is given nearly every year that exchange rate variations are overshooting what is required by fundamental economic adjustment. The rationale behind exchange rate volatility is justified by portfolio managers' expectations and their desire and duty to maximise long-term profits. It does not always fit with the needs of businesses, which can disappear before long-term achievements are visible. Therefore the current exchange rate volatility is detrimental for Europe.

An additional difficulty derives from the fact that exchange rate variations within the European Union are partly triggered by external exogenous shocks. The depreciation of the US dollar triggers transfers to the Deutsche Mark more than to other European currencies.

* Director General, European Monetary Institute, Frankfurt. Comments presented at the General Assembly of the Geneva Association, Lisbon, May 25, 1995. 
This is, of course, the result of the reputation acquired by this currency over a period of time. However, without the large imbalances experienced between the United States and Japan, such disturbances would not have occurred. The search for a safe haven when the Mexican crisis burst was, similarly, an exogenous shock for Europe. The European Union could, and should, avoid becoming a casualty when such unforeseeable events occur.

How does the single currency, as one of the features of a multinational domestic market, go along with economic integration? In this field, no crisis could stop the evolution towards increasing bilateral trade, standardisation of industrial processes and harmonisation of national rules. This will call for a single currency.

Similarly, low inflation in a number of member countries also makes it easier to substitute a common currency for the national ones.

2. One may wonder, however, why markets do not draw the right conclusions from these facts by maintaining stable exchange rates spontaneously. In order to do so, they would have to be fully reassured of the sustainability of similarly low inflation rates. Indeed, inflation is a complex phenomenon. Markets certainly welcome the independence of central banks and their increasing aversion to inflation. However, they also consider less satisfactory indicators, such as the fiscal stance as it is. Similarly, they take into consideration the pressure of unemployment or the lack of social cohesion.

Most of the convergence criteria listed in the Maastricht Treaty as preconditions for adopting the single currency will disappear when this goal is reached, as there will be no intrazone exchange rates any more, one rate of inflation and a single yield curve. Only the fiscal criteria will exist to ensure that the global policy mix is sound and that no government is heavily drawing resources from the global reservoir of private savings. At some stage the market might become the policeman and punish issuer States by requesting a rish premium. Firms would therefore be sheltered from the crowding-out effects we are now experiencing at a national level, when an excessive budget deficit triggers an increase in nominal longterm interest rates.

It is striking to see how important these fiscal criteria have become for member countries, both as the key with which the door of the monetary union could be opened and because fiscal consolidation per se is needed.

3. In the near future, the technical preparation of the final stage is actively pursued, even if the process is slower than some would have expected.

This is all the more true in the field of central banking. The EMI was set up at the beginning of 1994, as was laid down in the Maastricht Treaty, in spite of recent exchange crises and growing scepticism in some circles. Concrete achievements have already been made on practical issues such as the design of banknotes or the adaptation of payment systems.

However, some of the convergence criteria are not met today. Therefore we are still uncertain about the list of countries which will belong to the single currency area, as well as the precise date at which monetary union will become effective. Because of the difficulty of meeting the preconditions earlier, it is likely that monetary union will begin in January 1999. Many decisions leading to money being spent or the institutional framework being changed will probably be postponed until the decision is made by the Heads of State or Government. 
They will have to determine the timespan between their decision and the beginning of monetary union (Stage III). This interim period is necessary for implementing some legislative reforms and - in my field - for setting up the European Central Bank. This implies first the appointment of the members of the Direktorium. The single central bank will be a federal one. The Council will be the single decision-making body. National central banks will be the arms and the hands, not the brain and the voice. The Council will have to meet to decide upon the final choice of instruments.

As soon as the list of countries becomes official, there will be a strong incentive for all agents - Governments, administrations, national central banks, banks and non-banks - to complete the process on the basis of the preparatory work.

Governors would prefer the interim period to last around a year. This has been taken on board by the Commission in its Green Paper.

The next step will be the start of Stage III. We know for sure that there will be:

- no exchange rate intrazone, only conversion rates as long as we still have assets denominated in former national currencies;

- one central bank;

- one monetary policy;

- one yield curve as a consequence.

The EMI is working on the instruments of monetary policy and will resume work on targeting in the autumn. The issuance of banknotes and coins will be delayed. The Governors suggested that this should be by a period of two or three years. This length of time is justified not only, maybe not mainly, by the technical constraints to print banknotes, make coins, and distribute them over the territory, but also to give economic agents enough time to prepare themselves for the changeover.

What is still under discussion is how banking and payment systems will adjust. It is generally recognised that retail banking will follow the same path as banknotes and coins. However, there is a good case for making use of the Ecu from the start on some active markets, such as the money and foreign exchange markets, in order to increase the credibility of monetary union and to make it clearly irreversible. We still have to clarify if this will be the case, the extent to which the Ecu will be used either as a unit of account or as a means of payment before new banknotes are introduced, and how to organise this transitory period at the beginning of Stage III.

This transitory period should be given a clear deadline from the start, so that all economic agents know in advance how long they can take to adjust to the changeover. This will make them able to plan their preparatory work.

The changeover will not only affect money and foreign exchange markets, but also securities markets which are of paramount importance for insurance companies. The date at which the quotation will shift from national denominations to the Ecu and the date at which the changeover will apply to the settlement of transactions, will have to be elaborated further in connection with exchanges.

All this is feasible, although somewhat complex, provided we have the will and it is justified for the good of our peoples. 